Henley. Both were in fabor of investigating the sumit region of Akutan volcano, especially since the weather was clear enough to see Akutan volcano when air-borne from Dutch Harbor. A smoky haze could be seen above Akutan volcano as they approached and sulfur gases were detected even before they reached the volcano. They then circled the steaming Akutan cinder cone several times, flying just above (approximately $100 \mathrm{~m}$ above) the rim of the Akutan caldera. Suddenly, the steaming cinder cone started to erupt ash, lapilli, and blocks of rock. Paul Mahoney took photographs (see figure). Fearing damage to the plane, Dave immediately left the caldera and completed his flight to the village. Dave estimated, while he was returning to Dutch Harbor about 20 minutes later, that the tephra cloud had reached a height of $2 \mathrm{~km}$ above the volcano (an altitude of $3.3 \mathrm{~km}$ ). No ash-fall occurred at Akutan village during this particular eruption.

Sources of information:

Paul Mahoney, Dutch Harbor, Alaska, U.S.A.

Pilot Dave Henley of Airpac Inc., Dutch Harbor, Alaska, U.S.A.

Nancy and Dick Maloney of Airpac Inc., Dutch Harbor, A] Alaska, U.S.A.

Anna McGlashan, Akutan, Alaska, U.S.A.

Nick Borenin, Akutan, Alaska, U.S.A.

Larry Minsorf, Akutan, Alaska, U.S.A.

Charles McGlashan, Akutan, Alaska, U.S.A.

Lorrie Mason of Airpac Inc., Dutch Harbor, Alaska.

Pilot Nicho1 P. Sias of Airpac Inc., Dutch Harbor.

Nancy Gross, Unalaska City Manager, (formerly Akutan City Planner) Dutch Harbor, Alaska, U.S.A.

INSTRUMENTAL OBSERVATIONS

Seismograph: none

Aerial observations: conducted

Observations made from an Airpac Inc. Grumman

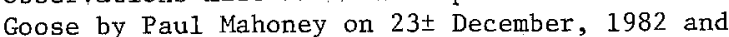
by pilot Dave Henley on $22 \& 23 \pm$ December, 1982.

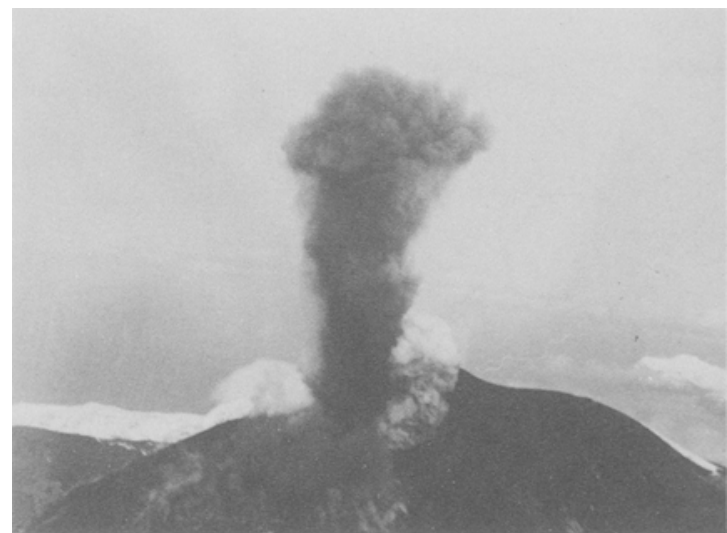

A view to the ENE of the initial phase of an eruption of Akutan volcano taken by Paul Mahoney

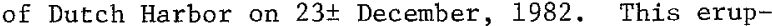
tion column reached a height of about $2 \mathrm{~km}$ above the erupting cone, which is centrally located inside Akutan summit caldera.

\section{DETAILS OF THE ERUPTION}

A) Vertical explosion; occurred The explosion was essentially magmatic. Several small ash-falls occurred at Akutan village, which is located $12 \mathrm{~km}$ to the east of Akutan volcano.

B) Volcani-clastic flow: none

C) Lava eruption: none

D) Notable topographic change: none

E) Damage: none
ERRATA B.V.E., No.22 (1984)

On page 92 of the last paragraph, the second sentence should read as "A NS oriented lake has formed (1980 Aug. observ. again) against the NW side of the 1958 lava flow, and this lake has flooded part of the northcentral part of the caldera."
On page 93 of the first paragraph, the second sentence should have one of the following phrases "is 12 times larger than the estimated volume of previous 1945 flows," deleted since it was stated twice. Also, in the last sentence of this same paragraph, "Fluctuating" should not have been capitalized, but instead "fluctuating". 